\title{
Fiscal Policy and Economic Growth in the Countries of the West African Economic and Monetary Union (WAEMU)
}

\section{Dr N'DIAYE Mamadou}

Faculty of Economics and Management of the University of Social Sciences and Management of Bamako, Mali E-mail: madou1573@yahoo.fr

\section{Dr SANOGO Boubacar (Corresponding Author)}

Faculty of Economics and Management of the University of Social Sciences and Management of Bamako, Mali Email: bacarsanogo@yahoo.fr

\author{
Article History \\ Received: 18 December, 202 \\ Revised: 21 January, 2022 \\ Accepted: 2 February, 2022 \\ Published: 6 February, 2022 \\ Copyright (C) 2022 ARPG \& \\ Author \\ This work is licensed under the \\ Creative Commons Attribution \\ International \\ (c) (1) CC BY: Creative \\ Commons Attribution License \\ 4.0
}

\begin{abstract}
This article focuses on the relationship between certain fiscal policy instruments and economic growth in the countries of the West African Economic and Monetary Union (WAEMU), namely Benin, Burkina Faso, Ivory Coast, Mali, Niger, Senegal, and Togo. Our growth model was estimated using the "Generalized Method of Moments (GMM) in a system" dynamic panel over the period 1990-2020. The results obtained show that total public revenue excluding grants, total expenditure, external public debt, the active population, and credits to the economy over GDP positively and significantly influence the GDP growth rate. On the other hand, an inflationary environment and poor quality of the Institutions negatively and significantly affect the rate of GDP growth. By way of economic policy implications, the WAEMU countries should reduce the distortions associated with taxation in order to maintain a fairly substantial level of resources and gradually break away from external forms of financing. Finally, financial development must be promoted so that companies can obtain more loans from banks.
\end{abstract}

Keywords: Fiscal policy; Growth; Quality of institutions; WAEMU.

\section{Introduction}

Economic growth appears to be an essential element in order to accelerate the process of economic development. However, economic growth does not happen spontaneously. In other words, to achieve the conditions for creating wealth, countries must implement policies that can influence the economy. One of the ways to do this is through fiscal policy. Budgetary policy is essentially carried out by the government and according to Keynesian theory, budgetary policy is an instrument that the State manipulates for the purposes of cyclical stabilization (policy of action on aggregate demand) or structural (budgetary policies intended to promote Economic Growth). However, the effects of fiscal policy are still debated in the economic literature. There is fierce opposition between economists in favor of state intervention and classical and neoclassical economists who oppose any state intervention. For Keynesians, budget spending encourages economic growth by stimulating household consumption and enabling investment. For the classics, the crowding out effects are far too great to have a positive effect on consumption and investment. The West African Economic and Monetary Union (WAEMU) was created on January 10, 1994 and the Treaty entered into force on August 1, 1994, after its ratification by member states. The states that make up this union are Benin, Burkina Faso, Ivory Coast, Guinea-Bissau, Mali, Niger, Senegal and Togo. In the 1990s, there was a real modernization of public finance management in WAEMU. The system has been subject to directives which harmonize laws and practices in various fields. For example, in line with international trends, a directive on finance laws presents new rules for the preparation, execution and evaluation of national budgets, recommending greater efficiency in public spending and public policy related. Recently, in the context of the 2009 directives, we have seen the creation of the legal, accounting and statistical framework for performance-based budget management. The 2009 directives are the second generation of directives forming the harmonized framework for public finances within WAEMU. This model organic law, relating to finance laws, implies the adoption of a program budget system where the annual budget appropriations appear in the form of programs and where the annual and medium-term performance targets and the annual reports of performance are worked out. The performance management of public finances is therefore becoming the norm.

Performance refers to the consideration of economy, effectiveness and efficiency. What spinoffs can WAEMU member countries expect from effective management of fiscal policy instruments? In other words, can an effective fiscal policy sustainably raise the growth rate of an economy?

This article, far from being a study of the determinants of economic growth in WAEMU, is intended to be a modest contribution to understanding the link between fiscal policy instruments and economic growth. More 
specifically, the article seeks to determine, apart from the control variables, the effects of public expenditure and public revenue on economic growth. Our article is of particular interest at a time when the interests of countries must be combined with community interests in order to achieve the promotion of a better and more shared living environment.

The article will cover the following sections. In a first section (1) we will review the theoretical and empirical literature on fiscal policy. A second section (2) will relate to the analysis of the effects of fiscal policy instruments on economic growth. A third section (3) will present and interpret the results. A fourth section (4) will be reserved for the conclusion and the implications of economic policy.

\section{Literature Review}

The effects of fiscal policy on the economy have been the subject of debate in the economics community since the turn of the 20th century and the emergence of Keynesian interventionist ideas. This theoretical opposition was first focused on the short term from a demand perspective, then extended to the long term from a supply perspective from the middle of the last century. This debate has become even more pronounced since the economic crisis of the beginning of the 21 st century and the dwindling financial resources of countries.

A brief review of the theoretical and empirical literature makes it possible to approach this controversy by starting from the classification made by Boskin (1988) into three levels: brake on growth by crowding out investments, neutrality of fiscal policy and finally support for growth and reduction of unemployment.

\subsection{Fiscal Policy Slows Down Economic Growth}

The neoclassical approach, and in particular that of the monetarists, became dominant from the 1960s, according to Bernheim (1989), thanks in part to the insistence on the notion of the crowding out effect. For the latter, deficits cause significant crowding-out effects which slow down growth prospects and accelerate external indebtedness. Thus, for Friedman (1970), fiscal policy without an accompanying monetary policy has no significant effect on economic growth. These crowding out effects are of two types: on the one hand, direct crowding out, qualified as ultra rationality, which postulates that any increase in budget spending is accompanied by a drop in consumption or private investment, rational economic agents, anticipating a substitution of the latter by state spending. This hypothesis is particularly valid, according to Peltzam (1973), for education and health expenditure as well as pension contributions. On the other hand, an indirect eviction, when the state finances its deficit in the financial markets, increasing borrowing and thus interest rates. Private demand for the latter, especially investment, is declining in response to this increase. Likewise, issuing a domestic debt, in a situation close to full employment, increases the wealth of private agents who increase their consumption at the expense of investment.

However, Keynesian economists criticize this crowding out effect by considering that a budget deficit has a positive and rapid impact on income which makes it possible to generate new savings and therefore an increase in borrowing which makes it possible to satisfy new demand without significant increase interest rates.

In the neoclassical line, there is a current of hyper classical economists who insist on the negative effects of fiscal stimulus policies and advocate austerity policies whose benefits they demonstrate, mainly through empirical studies. Thus, by studying budget contractions in ten European countries, Giavazzi and Pagano (1990) demonstrate that these austerity policies, lower spending or higher taxes have a positive effect on economic growth. The same results are found in the study of Alesina and Perotti (1995) and, to a lesser extent, that of Cour and Pisani-Ferry (1995).

On the other hand, Hellwing and Neumann (1987), explain that the direct effect of a budgetary contraction is negative on economic growth, however, the indirect effect induced on aggregate demand by the optimistic expectations of economic agents is positive, making it possible to cover the negative impact. This theory is, according to the authors, valid if the fiscal policy is credible, pursuing an objective of budgetary consolidation in the medium and long term.

\subsection{Neutral Fiscal Policy}

The neutrality of fiscal policy is associated in particular with the ricardian equivalence theory which was rehabilitated by Barro (1974). This theory is based on the principle that rational households develop an intertemporal and intergenerational consumption and savings plan described as optimal, according to Solow (2002), according to the theory of permanent life-cycle income. Households are considered ricardians if they know and incorporate the state's inter-temporal equilibrium constraint into their expectations. So, the latter anticipate a rise in taxes following an increase in the public deficit, public expenditure, in this sense, they do not consider the public debt as wealth for them. Thus, following a policy of budgetary expansion, the disposable income of households increases. However, the latter anticipate additional taxes in the future, intended to finance the loan which was used to carry out the expansionary fiscal policy. In fact, households return to their optimal inter-temporal allocation. In this sense, households generate additional private savings which offsets public dissaving, leaving national savings unchanged, equivalence between public and private savings, which explains the neutrality of fiscal policy within the meaning of the principle of equivalence ricardian. This theory is empirically verified in a recent survey carried out by Shapiro and Slemrod (2009).

Moreover, the theory of real business cycles, introduced by Kydland and Prescott (1982) and then extended by Long and Plosser (1983), denies any impact on fiscal policy. This theory is based on the demand for a single rational agent with "standard mathematical properties" which maximizes an additive utility function under certain 
constraints. These constraints allow only one equilibrium, that of pure and perfect competition. In this theory, the public sector levies the taxes necessary to finance its exogenous expenditure. Thus, these economists postulate the hypothesis that real variables cannot be affected by nominal variables and lead to the fact that real cycles can only be explained by stochastic technological shocks, the latter modifying the path of growth itself. Even without affecting the well-being of economic agents who react in an optimal way. In this context, the economy is still in a stable equilibrium. Thus, according to Solow (2002), fiscal policy is of no use as a policy of cyclical stabilization.

\subsection{Fiscal Policy Supports Economic Growth}

For Keynes, discretionary fiscal policy acts on effective demand, by stimulating the expectations of economic agents in terms of consumption and investment but also by a rise in prices which reduces real interest rates and wages allowing to exceed rigidities in the labor market and further stimulate economic growth. These contributions are formalized in a synthesis with neoclassical theories to form the IS-LM model or Hicks-Hansen model. Moreover, in an open economy, the work of Mundell and Fleming, on the IS-LM-BP model, shows that the effectiveness of fiscal policy varies according to the exchange rate system and the duration of interventions. In flexible exchange rates, a permanent budgetary policy modifies the expectations of economic agents causing a significant appreciation of the exchange rate which crowds out the initial positive effects. However, if this policy is temporary, expectations do not follow and the appreciation of the exchange rate is less important, leaving some effectiveness to the latter. At fixed exchange rates, the crowding out effect by the exchange rate is not exist, inducing a very efficient fiscal policy, but the intervention of the Central Bank to maintain it causes high inflation, which may reduce the competitiveness of the economy.

From the point of view of the supply economy, centered mainly on the effect of tax levies on short-term private initiatives, the Keynesian effect is valid, while in a long-term perspective the decline in taxation reduces the private net return, hence investment and production. Moreover, the Laffer curve fixes an optimal tax point above which the effects of fiscal policy reverse. Arvisenet (1984), broadens the analysis by indicating that the different types of taxes do not have the same effects on the behavior of economic agents and recommends in this sense the analysis of the effect of each type of tax and its magnitude separately.

In addition, the theories of endogenous growth, particularly the AK model, due to the contributions of Romer (1986) and Rebelo (1991), make it possible to explain economic growth as a function of three factors, taken up by Deiss and Gugler (2012): accumulation of physical capital, research and development and human capital. This theory emphasizes the role of investments in capital accumulation as the main source of growth. Thus, certain economists, including Aschauer (1989) and Barro (1990), distinguish in their production function between two components of capital: private capital and public capital. In addition, the latter consider that public and private capital are accumulable and generate sustained growth. For Barro (1990), higher taxes can promote growth, by allowing greater public investment, if this increase compensates for the decline in private investment. Hence the existence of the optimal tax rate mentioned above. This theory is confirmed by the empirical work of Munnel (1992) and Mills and Quinet (1992).

Finally, the theory of real cycles was taken up by the new Keynesians who introduced new hypotheses allowing a certain effect to economic policies. It is, among other things, a gradual adjustment of prices as opposed to the immediate adjustment in the initial theory and the markets are not necessarily in a situation of pure and perfect competition, the economic cycle is affected by the real variables and nominal variables. In this situation, a cyclical fiscal policy can act on the level of production and prices but only in the short term, in the time interval of price adjustment. However, economic growth and prices return to their initial level after some time, in the absence of a technology shock. This theory is confirmed by recent empirical studies, in particular those of Fatas and Mihov (2001), Blanchard and Perotti (2002), Cwik et al. (2010), Cogan et al. (2010) or Strulik and Trimborn (2013) who demonstrate a significant immediate impact that weakens over time, even going so far as to be reversed in some studies.

\subsection{Variation in the Effects of Fiscal Policy According To Its Components}

Several alternative approaches have developed over the past decades distinguishing between the effects of the different components of fiscal policy. Thus, the empirical study of Landau (1986) and later Barro (1991) leads to a negative relationship between public consumption, excluding education and military spending, and economic growth, while spending on education and investment stimulate economic growth. These results are confirmed in the study of Easterly and Rebelo (1993) or the study of Aghion et al. (2006). Along the same lines, Alesina and Perotti (1995) show that, in the case of austerity policy, cuts in current budgetary expenditure, particularly salaries and transfers, give positive results, while policies including tax increases or lower investment spending have a negative effect.

Several studies on the effects of fiscal policy have been carried out on WAEMU. For example, the study by Beni et al. (2016) estimates the influence of fiscal policy on the development of economic activity in the WAEMU zone, conditional on the level of external debt. The results of the study show that debt significantly and negatively influences the effectiveness of fiscal policy. The impact of fiscal policy on growth gradually decreases as the level of external debt increases. Another example relates to the study conducted by Diop and Diaw (2015). The authors highlight the reaction functions of economic activity in WAEMU countries following fiscal shocks using a 2-lag structural autoregressive vector model (SVAR). They thus show how budgetary policy shocks propagate in the economic activity of the countries of the Union and attempt to this end to bring out its transmission mechanisms. In addition, the results of studies carried out by Nubukpo (2007) and N'Guessan (2007) on the WAEMU countries 
show a negative effect of current expenditure on private investment and economic growth while public investment stimulates the latter two, but only in the long run.

For developing countries in general, we retain the study by Samaké et al. (2013) on Cameroon. The authors find a strong impact of investment spending on economic growth, especially when the latter are financed by rent.

\section{Analysis of the Effects of Fiscal Policy on Economic Growth 3.1. Presentation of the Empirical Model and Variables}

This study is based on a model developed by the World Bank (2002) which is particularly suited to developing countries. This model is taken up by Nubukpo (2007) and extended by N'Guessan (2007). But unlike these authors, we specify our base model starting from a Cobb-Douglas production function.

Where,

$$
Q_{i t}=A_{i t} K_{i t}^{\alpha} L_{i t}^{\beta}
$$

$\mathrm{Q}_{\mathrm{it}}$ is the gross domestic product (GDP) of country $\mathrm{i}$ at time $\mathrm{t}$;

$\mathrm{K}_{\mathrm{it}}$ is the physical capital of country $\mathrm{i}$ at time $\mathrm{t}$;

$\mathrm{L}_{\mathrm{it}}$ is the human capital of country $\mathrm{i}$ at time $\mathrm{t}$;

$\mathrm{A}_{\mathrm{it}}$ is the technical progress of country $i$ at time $t$.

Since economic growth is a dynamic variable, we can transform output $Q$ into a growth rate of gross domestic product. Let $Y_{i t}$ be the growth rate of gross domestic product. Thus, we will have:

$$
\begin{gathered}
Y_{i t}=\frac{Q_{i t-} Q_{i t-1}}{Q_{i t-1}}=>Y_{i t} * Q_{i t-1}=Q_{i t}-Q_{i t-1}=>Y_{i t} * Q_{i t-1}+Q_{i t-1}=Q_{i t} \\
\Leftrightarrow Q_{i t}=Q_{i t-1}\left(Y_{i t}+1\right)
\end{gathered}
$$

Replace the value of $\mathrm{Q}_{\mathrm{it}}$ from equation (2) in equation (1), we will have:

$$
Q_{i t-1}\left(Y_{i t}+1\right)=A_{i t} K_{i t}^{\alpha} L_{i t}^{\beta}=>Y_{i t}=\frac{A_{i t} K_{i t}^{\alpha} L_{i t}^{\beta}}{Q_{i t-1}}-1
$$

By performing a logarithmic transformation, equation (3) becomes:

$$
\log Y_{i t}=\log A_{i t}+\alpha \log K_{i t}+\beta \log L_{i t}-\log Q_{i t-1}-\log 1
$$

We know that $\log 1=0$, so equation (4) becomes:

$$
\log Y_{i t}=\log A_{i t}+\alpha \log K_{i t}+\beta \log L_{i t}-\log Q_{i t-1}
$$

In equation (5), the exogenous variables of the model, i.e. the two factors of production $\mathrm{K}$ and $\mathrm{L}$ can be disaggregated using proxy variables. For human capital $\mathrm{L}$ we will use a variable representing the active population, also used by Nubukpo (2007). For physical capital we use the formulation of N'Guessan (2007) to determine the factors that influence changes in capital. Thus, the latter fluctuates according to total real public expenditure and total public revenue.

Our model can be rewritten as follows:

$$
\log Y_{i t}=\beta_{0}+\beta_{1} \log Q_{i t-1}+\beta_{2} \log K_{i t}+\beta_{3} \log L_{i t}+\beta_{4} X_{i t}
$$

Where, $X_{\text {it }}$ the model's control variables which are: the rate of inflation, external public debt and credits to the economy as a percentage of GDP.

The general model to be tested is:

LTXPIB $_{i t}=\delta_{0}+\delta_{1} L_{P I B I N I T}{ }_{i t-1}+\delta_{2}$ LPREPUB $_{i t}+\delta_{3}$ LDEPUB $_{i t}+\delta_{4}$ LPOPACTIV $_{i t}+\delta_{5}$ INFLA $_{i t}+$ $\delta_{6} L D E T P U B_{i t}+\delta_{7} C_{R E D E C O}+\delta_{8} I N D L I B R E_{i t}+\mu_{i}+\theta_{t}+\epsilon_{i t}$

Where,

Regarding the variables of interest, we have:

LTXPIB: is the logarithm of the growth rate of gross domestic product (GDP). This is the explained variable that represents economic growth. This variable comes from data from the Central Bank of West African States (CBWAS).

LPIBINIT: is the logarithm of the initial level of GDP, or the GDP at the beginning of the period, which is measured by the values of the GDP delayed by one year compared to the study period. According to the neoclassical growth theory (Roubini and Sala-i-Martin, 1995), taking into account the initial level of GDP makes it possible to test the convergence hypothesis. This variable comes from data from the CBWAS.

LPREPUB: is the logarithm of total government revenue excluding grants representing the capacity of government to levy taxes and mobilize domestic resources. This variable comes from data from the CBWAS.

LDEPUB: is the logarithm of total public expenditure representing the State expenditure for the realization of projects listed in the Finance Law. This variable comes from data from the CBWAS.

LPOPACTIV: is the logarithm of the level of the labor force representing the number of individuals of working age. This variable comes from the World Bank's World Development Indicators (WDI).

Apart from the variables relating to fiscal policy, we know that economic growth is influenced by a number of control variables. In this article, we have retained:

INFLA: is the rate of inflation, measured by the relative change in the consumer price index. The literature suggests that the link between inflation and growth is non-linear. At low levels of inflation, upward changes in inflation have only a negligible negative impact on growth rates. In contrast, at high levels of inflation (above 30$40 \%$ per annum) stabilizing inflation leads to higher growth rates. This variable comes from data from the CBWAS.

LDETPUB: is the logarithm of the external public debt representing the level of external debt of the government. This variable comes from data from the CBWAS. 
CREDECO: is the ratio of loans to the economy to GDP and it measures the degree of intermediation of the economy. Excluding the public sector, this indicator highlights the proportion of resources devoted to private investment. This ratio comes from data from the CBWAS.

INDLIBRE: is an indicator of the quality of the legal environment or the quality of institutions, measured by the Civil Liberties Index. Civil liberty includes free expression, the quality of institutions and individual autonomy without the interference of public powers. This index, constructed on a scale of 1 to 7 , decreases with the improvement of the legal environment. This variable comes from the Freedom House database.

$\varepsilon$ : the error term; $\mu$ : the specific country effect; $\theta$ : the specific period effect; i: the country index and t: the period index.

\subsection{Data Analysis}

The descriptive statistics and the correlation table of the variables are presented in Tables 1 and 2, respectively.

Table-1. Descriptive statistics

\begin{tabular}{l|l|l|l|l|l}
\hline Variables & Mean & Standard deviation & Minimum & Maximum & Observations \\
\hline TXPIB & 9.65098 & 43.08412 & -74.19148 & 329.644 & 217 \\
\hline PREPUB & $7.83 \mathrm{e}+11$ & $8.69 \mathrm{e}+11$ & $3.83 \mathrm{e}+10$ & $5.10 \mathrm{e}+12$ & 217 \\
\hline DEPUB & $1.04 \mathrm{e}+12$ & $1.08 \mathrm{e}+12$ & $9.31 \mathrm{e}+10$ & $6.86 \mathrm{e}+12$ & 217 \\
\hline POPACTIV & 4393177 & 1839173 & 1195890 & 8749634 & 217 \\
\hline PIBINIT & $5.47 \mathrm{e}+12$ & $4.99 \mathrm{e}+12$ & $2.93 \mathrm{e}+11$ & $2.82 \mathrm{e}+13$ & 217 \\
\hline INFLA & 3.15421 & 6.814095 & -5.97894 & 57.71028 & 217 \\
\hline
\end{tabular}

Tables 1 show that the average economic growth rate is $9.65 \%$. Its minimum value is in Togo $(-74.19 \%)$ while its maximum value is in Ivory Coast $(329.64 \%)$. The minimum value for total government revenue excluding grants ( 38.3 billion) is recorded in Togo, while the maximum value is in Ivory Coast (5100 billion). For total public expenditure, the highest level is in Ivory Coast (6860 billion) and the lowest level is in Togo (93.1 billion). The highest value of the economically active population is in Niger (8749634) and its lowest value is in Togo (1195890). And finally, the minimum value of the inflation rate is in Mali $(-5.98 \%)$ and the maximum value is in Togo $(57.71 \%)$.

Table-2. Correlation between variables

\begin{tabular}{l|l|l|l|l|l}
\hline Correlation Matrix & TXPIB & PREPUB & DEPUB & POPACTIV & INFLA \\
\hline TXPIB & 1.0000 & & & & \\
\hline PREPUB & -0.0737 & 1.0000 & & & \\
\hline DEPUB & -0.0723 & 0.9897 & 1.0000 & & \\
\hline POPACTIV & -0.0902 & 0.6020 & 0.6329 & 1.0000 & \\
\hline INFLA & -0.0208 & -0.1534 & -0.1581 & -0.1651 & 1.0000 \\
\hline
\end{tabular}

Regarding Table 2, two observations are worth making. First, there is a negative correlation between fiscal policy instruments and the rate of economic growth. There is also a positive correlation between the different fiscal policy variables. Then, we notice that inflation is negatively correlated with all the other variables.

\subsection{Presentation of the Econometric Method}

The estimation of equation (7) will be done using the Generalized Method of Moments (GMM) in dynamic panel. A dynamic model is a model in which one or more lags of the dependent variable appear as explanatory variables. Unlike dynamic panel GMMs, standard econometric techniques such as ordinary least squares (OLS) do not allow unbiased estimates of such a model to be obtained, because of the presence of the dependent variable lagged to the right of the equation. In particular, GMM estimation makes it possible to deal with the problem of the endogeneity of variables. Specifically, in this paper we use the GMM System estimator from Blundell and Bond (1998). This technique was initiated by Arellano and Bover (1995) and subsequently developed by Blundell and Bond (1998). It combines the first difference equations with the level equations. In addition, Blundell and Bond (1998) have shown using Monte Carlo simulations that the GMM System estimator is more efficient than that in first differences (Arellano and Bond, 1991). The latter gives biased results in finite samples when the instruments are weak. The GMM System method meets the need for the study of panel data by providing solutions to the most frequent problems in this field: the heterogeneity of the behaviors of the individuals in the sample, endogeneity (presence of lagged endogenous variables among the regressors of the model) and the simultaneity (bidirectional causality problem between variables). To test the validity of lagged variables as instruments, Arellano and Bond (1991), Arellano and Bover (1995), Blundell and Bond (1998) suggest the Sargan or Hansen test and the second order autocorrelation test. The statistic of the Sargan or Hansen test is that of the two-step System GMM estimation procedure. Unlike the statistic obtained in the single-step estimation procedure, this statistic is robust to the presence of heteroskedastic errors (Arellano and Bond, 1991).

\section{Presentation and Interpretation of the Results}

The results of the estimated equation (7) are shown in Table 3 above. 
Table-3. Relationship between growth and fiscal policy

\begin{tabular}{l|l|l|l|l|l}
\hline $\begin{array}{l}\text { Explained variable : GDP } \\
\text { growth rate (in Log) }\end{array}$ & $\mathbf{( 1 )}$ & $\mathbf{( 2 )}$ & $\mathbf{( 3 )}$ & $\mathbf{( 4 )}$ & $\mathbf{( 5 )}$ \\
\hline LPIBINIT & $-3.897 * * *$ & $-3.754 * * *$ & $-4.304^{* * *}$ & $-4.457 * * *$ & $-3.996^{* * *}$ \\
\hline & $(0.377)$ & $(0.501)$ & $(0.624)$ & $(0.700)$ & $(0.543)$ \\
\hline LPREPUB & $2.002 * * *$ & & & & \\
\hline LDETPUB & $(0.222)$ & & & & \\
\hline & $0.809 * *$ & $0.787 * *$ & $2.499 * * *$ & $2.609 * * *$ & $2.241^{* * *}$ \\
\hline LDEPUB & $(0.225)$ & $(0.283)$ & $(0.649)$ & $(0.678)$ & $(0.584)$ \\
\hline LPOPACTIV & & $2.163 * * *$ & & & \\
\hline & & $(0.348)$ & & & \\
\hline INFLA & & & $2.482^{* * *}$ & $2.469 * *$ & \\
\hline & & & $(0.602)$ & $(0.681)$ & \\
\hline CREDECO & & & & $-0.0412 * *$ & \\
\hline INDLIBRE & & & & $(0.0152)$ & \\
\hline & & & & & $0.128 * * *$ \\
\hline Constant & & & & & $(0.0291)$ \\
\hline & & & & & $-0.435 *$ \\
\hline Observations & $38.32 * * *$ & $29.75 * *$ & $19.01 * *$ & $20.87 * *$ & $54.40 * *$ \\
\hline Countries & $(8.045)$ & $(9.024)$ & $(7.049)$ & $(6.472)$ & $(16.57)$ \\
\hline Hansen Test & 177 & 177 & 177 & 177 & 156 \\
\hline AR(2) & 7 & 7 & 7 & 7 & 7 \\
\hline Not & 0.105 & 0.176 & 0.197 & 0.119 & 0.456 \\
& 0.161 & 0.212 & 0.667 & 0.172 & 0.779 \\
\hline
\end{tabular}

Notes: in parentheses, the value of the standard errors. * Significant at 10\%, ** Significant at 5\%, *** Significant at $1 \%$. AR (2): probability of the second order autocorrelation test of Arellano and Bond.

We made the choice to fix the initial GDP or the GDP lagged by one year compared to the study period and the public debt during the estimates. Indeed, it is assumed that the WAEMU countries are heavily dependent on external debt in order to meet the budget deficit. Thus, public debt and GDP at the start of the period appear in the five (5) columns of Table 3. Our results show that the coefficients of all the regressors in our model are significant.

At the level of all columns, the coefficients for initial GDP, or GDP lagged by one year from the study period, are negative and significant and those for external debt are positive and significant.

For example, in column 1, the coefficients of government revenue excluding grants and public debt are positive and significant. In other words, a $1 \%$ increase in government revenue excluding grants leads to an increase in economic growth of $2.002 \%$ and a $1 \%$ increase in public debt leads to an increase in economic growth of $0.809 \%$. Adding total government expenditure in column 2 shows that the coefficient for this expenditure is positive and significant. A $1 \%$ increase in public spending leads to an increase in economic growth of $2.163 \%$. The addition of the active population is done at two levels, in columns 3 and 4. For example, in column 4, we notice that the coefficient of the active population is positive and significant and that of inflation is negative and significant. An increase in the labor force of $1 \%$ results in an increase in the growth rate of $2.469 \%$, and an increase in inflation of $1 \%$ results in a decrease in the economic growth rate of $0.0412 \%$. In column 5 , we notice that the coefficient of the ratio of loans to the economy on GDP is positive and significant and that of the index of civil liberties is negative and significant. For example, an increase in the ratio of loans to the economy to GDP leads to an increase in the economic growth rate of $0.128 \%$ and an increase in the civil liberties index leads to a deterioration in the economic growth rate of $0.435 \%$.

The WAEMU countries can create wealth through the public levy that will be used to spend in the productive sectors. However, the WAEMU countries are still very dependent on foreign aid. This foreign aid serves them in particular to make up their budget deficit because the resources collected are insufficient to face major infrastructure projects and other investment expenses. But, the WAEMU countries can count on their human capital. Indeed, the positive and significant relationship that the working population maintains with growth should be encouraged and perpetuated. Financial development, captured by the ratio of credits to the economy to GDP, is favorable to economic growth within the WAEMU. Similar results proving that financial development has a positive and significant effect on economic growth are found by numerous studies, notably King and Levine (1993a), Rousseau and Watchell (2000), Beck and Levine (2004), Guillaumont-Jeanneney and Kpodar (2004). Banks in WAEMU countries participate in the creation of wealth through credits distributed to the economy. Moreover, even if the WAEMU countries are not at the same level of economic development, the results suggest that these economies will see their gross domestic product converge over time. In addition, poor quality institutions and an inflationary environment are detrimental to economic growth.

\section{Conclusion and Policy Implications}

In this article, we have investigated the relationship between economic growth and some fiscal policy instruments. To do this, we developed a testable equation of the economic growth rate over the period 1990-2020. 
Our method of investigation relied on the GMM System estimator. Our results show that the variables of total government revenue excluding grants and total expenditure positively and significantly influence the GDP growth rate. The same is true for the external public debt, the active population, the ratio of loans to the economy to GDP, which all have a positive and significant influence on the rate of GDP growth. On the other hand, an inflationary environment and of poor quality of the Institutions negatively and significantly affects the rate of GDP growth.

As an economic policy implication, the WAEMU countries must make efforts to invest in human development, rural development and infrastructure. These expenditures are often cited in the economic literature as generating positive externalities and therefore acting positively on the growth rate of the economy. In addition, States should reduce the distortions associated with taxation in order to maintain a fairly substantial level of resources, in particular by increasingly developing internal resources such as mining and the production of high value-added crops. This will allow the WAEMU countries to gradually break away from external forms of financing. In addition, the WAEMU states must clean up the business environment by adopting appropriate policies capable of supporting the private sector through tax incentives and intellectual property protection. In addition, WAEMU countries need to reduce their budget deficits in order to keep inflation at moderate levels and promote policies that help lower the speed of currency circulation. And finally, financial development must be promoted so that companies can get more loans from banks.

\section{References}

Alesina, A. and Perotti, R. (1995). Fiscal expansion and fiscal adjustements in oecd countries. Economic Policy, (21).

Arellano, M. and Bond, S. (1991). Some tests of specification for panel data: Monte Carlo evidence and an application to employment equations. The Review of Economic Studies, 58(2): 277-97.

Arellano, M. and Bover, O. (1995). Another look at the instrumental variable estimation of error component model. Journal of Econometrics, 68(1): 29-52.

Aghion, P., Cohen, E. and Pisanni-Ferry, J. (2006). Politique Economique et Croissance en Europe,. éd. La Documentation Française: Paris. 91-94.

Arvisenet, P. (1984). Une courbe de Laffer pour la France. 31(8).

Aschauer, D. (1989). Is public expenditures productive. Journal of Monetary Economics, 23(2): 177-200.

Barro, R. (1974). Are government bonds net wealth. The Journal of Political Economy, 82(6): 1095-117.

Barro, R. (1990). Government spending in a simple model of endogeneous growth. The Journal of Political Economy, 98(5): 103-25.

Barro, R. (1991). Economic growth in a cross section of countries. Quarterly Journal of Economics, 106(2): $407-43$.

Beck, T. and Levine, R. (2004). Stock markets, banks and growth: Panel evidence. Journal of Banking and Finance, 28(3): 423-42.

Beni, K. M., Yohou, H. D. and Ouattara, W. (2016). Effets de l'endettement public sur l'efficacité de la politique budgétaire dans l'espace UEMOA. Revue Economique et Monétaire de la BCEAO, (20): 35-69.

Bernheim, D. (1989). A neoclassical perspective on budget deficits. Journal of Economic Perspectives, 3(2): 55-72.

Blanchard, O. and Perotti, R. (2002). An empirical characterization of the dynamic effects of change in government spending and taxes on output. The Quarterly Journal of Economics, 117(4): 1329-68.

Blundell, R. and Bond, S. (1998). Initial conditions and moment restrictions in dynamic panel data models. Journal of Econometrics, 87(1): 115-43.

Boskin, M. (1988). Consumption, savings and fiscal policy. American Economic Review, 78(2): 401-07.

Cogan, J. F., Cwik, T., Taylor, J. B. and Wieland, V. (2010). New keynesian versus old keynesian government spending multipliers. Journal of Economic Dynamic and Control, 34(3): 281-95.

Cour, P. and Pisani-Ferry, J. (1995). Combien coûte un redressement budgétaire ? Une comparaison internationale. La Lettre du CEPII.

Cwik, T., Cogan, J. F., Taylor, J. B. and Wieland, V. (2010). New keynesian versus old keynesian government spending multipliers. Journal of Economic Dynamic and Control, 34(3): 281-95.

Deiss, J. and Gugler, P. (2012). Politique economique et sociale. éd. De Boeck Université, Bruxelles (Belgique).

Diop, M. and Diaw, A. (2015). Politique budgétaire et stabilité macroéconomique en union economique et monétaire : Le cas de l'uemoa. Revue de l'OFCE, (137): 181-209. Available: https://www.cairn.info/revue-de-l-ofce2015-1-page-181.htm

Easterly, W. and Rebelo, S. (1993). Fiscal policy and economic growth; an empirical investigation. Journal of Monetary Economics, 32(3): 417-58.

Fatas, A. and Mihov, I. (2001). The effects of fiscal policy on consumption and employment: Theory and evidence", CEPR discussion papers. (2760).

Friedman, M. (1970). A theorical framework for monetary analysis. The Journal of Political Economy, 78(2): 193238.

Giavazzi, F. and Pagano, M. (1990). Can sever fiscal contractions be expansionary? Tales of two small european countries. NBER Annual:

Guillaumont-Jeanneney, S. and Kpodar, K. (2004). Développement financier, instabilité financière et croissance economique. Économie et Prévision, 3(174): 87-111.

Hellwing, M. and Neumann, M. (1987). Economic policy in Germany: Was there a turnaround? Economic Policy, 2(5): 103-45. 
King, R. and Levine, R. (1993a). Finance and growth: Schumpeter might be right. The Quarterly Journal of Economics, 108(3): 717-37.

Kydland, F. and Prescott, E. (1982). Time to build and aggregate fluctuations. Econometrica, 50(6).

Landau, D. (1986). Government and economic growth in the less developed countries: An empirical study for 1960 80. University of Chicago Press. 35.

Long, J. B. and Plosser, C. L. (1983). Real business cycles. Journal of Political Economy, 91: 1.

Mills, P. and Quinet, A. (1992). Dépenses Publiques et Croissance. Revue Française d'Economie, 7(3).

Munnel, A. (1992). Infrastructure, investment and economic growth. Journal of Economic Perspectives, 6(4).

N'Guessan, G. A. (2007). Structure des dépenses publiques, investissement privé et croissance dans l'uemoa. Documents et Etudes de Recherche, 7(4).

Nubukpo, K. (2007). Dépenses publiques et croissance des pays de l'union economique et monétaire ouest africaine. Afrique Contemporaine, 22(2): 213-40.

Peltzam, S. (1973). The effects of public subsidies in kind on private expenditures: the case of higher education. The Journal of Political Economy, 81(1).

Rebelo, S. (1991). long run policy analysis and long run growth. Journal of Political Economy, 99(3): 500-21.

Romer, P. (1986). Increasing returns and long run growth. The Journal of Political Economy, 94(5): 1002-37.

Roubini, N. and Sala-i-Martin, X. (1995). A growth model of inflation, tax evasion and financial repression. Journal of Monetary Economics, 35(2): 275-301.

Rousseau, P. and Watchell, P. (2000). Inflation, financial development and growth, Economic theory, dynamics and markets: Essays in honor of Ryuzo Sato, Edité par T. Negishi, R. Ramachandran and K. Mino, Kluwer 2001.

Samaké, I., Muthoora, P. and Versailles, B. (2013). Viabilité budgétaire, investissement public et croissance dans les pays à faible revenu, riches en ressources naturelles : le cas du Cameroun », Fonds Monétaire international, WP/13/144.

Shapiro, M. D. and Slemrod, J. B. (2009). Did the 2008 tax rebates stimulate spending?", NBER working paper. (14753).

Solow, R. (2002). Peut-on recourir à la politique budgétaire? Est-ce souhaitable ? Revue de l'OFCE, N83, Octobre 2002.

Strulik, H. and Trimborn, T. (2013). The dark side of fiscal stimulus, discussion papers, center for european governance and economic development research. (150). 